Institute of $\mathbf{F}_{\text {ood and }} \mathbf{A}_{\text {gricultural }} \mathbf{S}_{\text {ciences }}$

\title{
Florida Dampwood Termites, Neotermes castaneus (Burmeister), Neotermes jouteli (Banks), and Neotermes luykxi Nickle and Collins (Insecta: Isoptera: Kalotermitidae) $)^{1}$
}

Rudolf H. Scheffrahn and Nan-Yao Su²

\section{Introduction}

Neotermes is a diverse genus of nearly 100 species that live mostly in the world's tropical areas. Species of Neotermes are the largest termites in the eastern United States. In the eastern U.S., they are found only in Florida. Unlike colonies of structure-infesting drywood termites (e.g. Cryptotermes and Incisitermes), Neotermes colonies require higher humidity and regular contact with free water, and unlike subterranean termites, they do not forage in the soil.

Over the years, common names have lead to some confusion. The common name for the Neotermes from Florida is not to be confused with that of Prorhinotermes simplex, a subterranean species (Family Rhinotermitidae) that, like Neotermes, often nests in fallen logs near coastal zones. Unfortunately, $P$. simplex has sometimes also been referred to as "the Florida dampwood termite" and, for this reason, Neotermes in Florida have alternatively been called "southern dampwood termites" Neotermes should also not be confused with Zootermopsis (Termopsidae), a primitive genus of "dampwood" or "rottenwood" termites from western North America.

\section{Distribution}

In the United States and its Caribbean territories, Neotermes are endemic to Florida, Hawaii, Puerto Rico, and the Virgin Islands. The three Neotermes species in Florida have various extended distributions that include the Bahamas, Cuba, and Mexico.

Neotermes are common in the subtropical woodlands, mangrove forests, and urban settings of the coastal peninsula of Florida and the Florida Keys (Figure 1). Neotermes castaneus has the greatest distribution in Florida with its northern limits extending to Merritt Island on the eastern coast and Pinellas County on the Gulf coast. Inland infestations of $N$. castaneus have been confirmed in Orlando and

1. This document is EENY-122 one of a series of Featured Creatures from the Entomology and Nematology Department, Florida Cooperative Extension Service, Institute of Food and Agricultural Sciences, University of Florida. Published: January 2000. This document is also available on Featured Creatures Website at http://creatures.ifas.ufl.edu. Please visit the EDIS Website at http://edis.ifas.ufl.edu. Additional information on these organisms, including many color photographs, is available at the Entomology and Nematology Department website at http://entnemdept.ifas.ufl.edu/.

2. Rudolf H. Scheffrahn, professor and Nan-Yao Su, professor, Entomology and Nematology Department, Ft. Lauderdale REC, University of Florida, Ft. Lauderdale, FL.

The Institute of Food and Agricultural Sciences is an equal opportunity/affirmative action employer authorized to provide research, educational information and other services only to individuals and institutions that function without regard to race, color, sex, age, handicap, or national origin. For information on obtaining other extension publications, contact your county Cooperative Extension Service office. Florida Cooperative Extension Service/Institute of Food and Agricultural Sciences/University of Florida/Christine Taylor Waddill, Dean. 
along the shore of Lake Okeechobee. The range of $N$. jouteli extends from Vero Beach to the Keys, while $N$. luykxi, a relatively newly discovered species, has been collected from eastern Broward County to Key Largo.

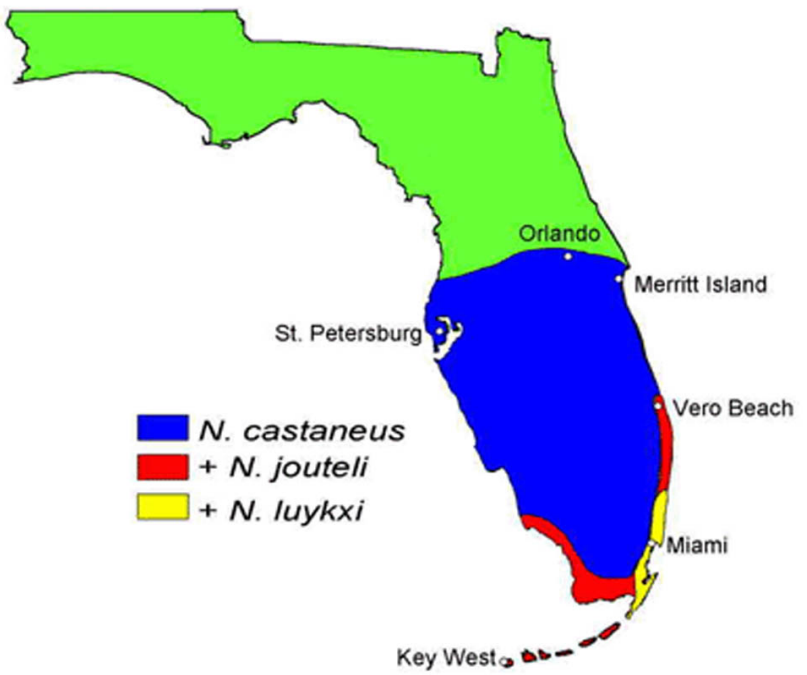

Figure 1. Distribution of Neotermes species in Florida. Credits: Rudolf H. Scheffrahn, University of Florida

\section{Description and Identification}

Colonies of dampwood termites consist of three primary castes: the reproductives (king, queen, and unmated winged forms called alates), soldiers, and false workers or pseudergates (Figure 2). Neotermes pseudergates are immature forms without external signs of wings. When wing buds become visible after molting, they are called nymphs. The pseudergates and nymphs excavate and feed on wood to nourish themselves and their nestmates. Eggs and newly hatched termites, called larvae, are usually found near the king and queen. Soldiers constitute about $5 \%$ of the colony population.

A month or two before dispersal flights, nymphs with long wing buds appear and gradually molt into alates. Neotermes alates are large and have two pairs of wings that are lightly creased along their vein paths. Fore wings and hind wings are about equal in size and shape. Each fore wing has five pigmented and enlarged veins (costal margin, subcosta, radius, radial sector, and median) near where they attach to the body (Figure 3 ). The enlarged median vein distinguishes Neotermes alates from all other termites in Florida (Figure 4).

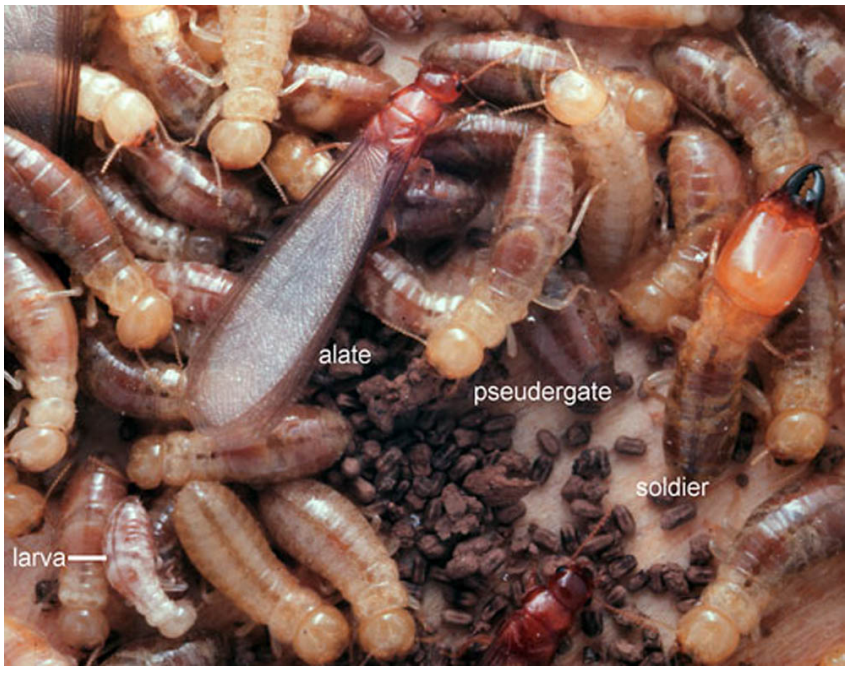

Figure 2. Castes in a Neotermes castaneus (Burmeister) colony. Credits: Rudolf H. Scheffrahn, University of Florida

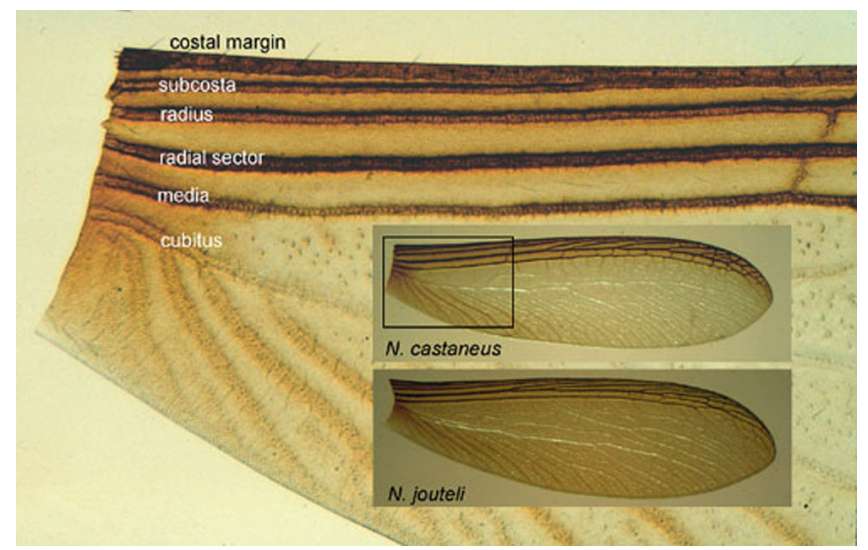

Figure 3. Neotermes fore wings. Credits: Rudolf $\mathrm{H}$. Scheffrahn, University of Florida

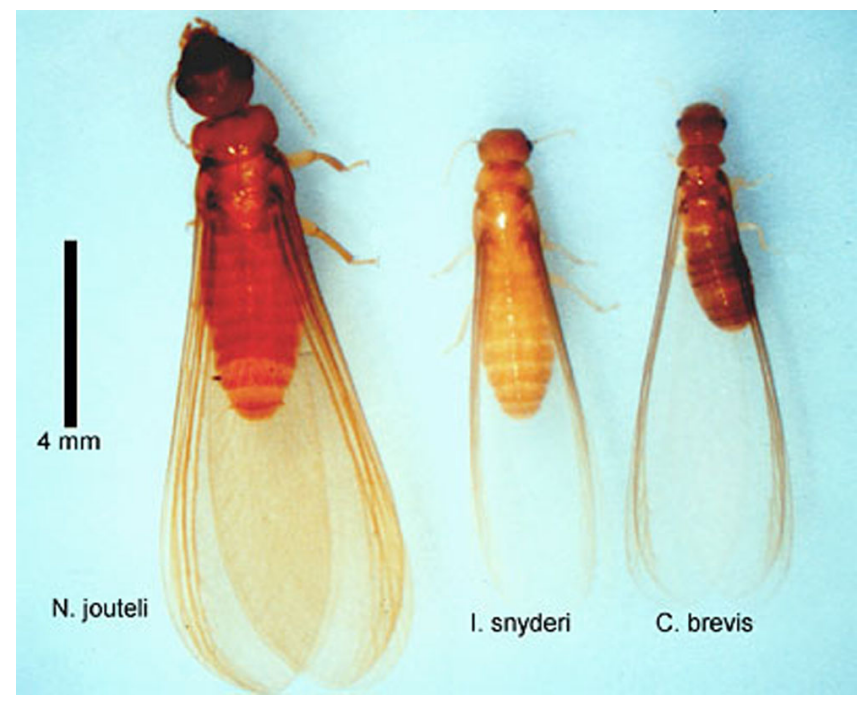

Figure 4. Neotermes jouteli (Banks) alate and alates of two drywood termite species found in Florida, Incisitermes snyderi and Cryptotermes brevis. Credits: Rudolf $\mathrm{H}$. Scheffrahn, University of Florida 
The following key can be used to further distinguish alates of the three species of Neotermes found in Florida:

1a. Head and pronotum sparsely covered with long (ca. 0.2-mm-long) hairs; body reddish-brown (Figure 5)...... castaneus

1b. Head and pronotum sparsely covered with short (ca. 0.05-mm-long) hairs; body reddish-orange (Figure 6) ..... 2

2a. Length with wings $12-14 \mathrm{~mm}$; head width at eyes $<=1.52 \mathrm{~mm}$; eye diameter $0.38-0.42 \mathrm{~mm}$; frons not deeply recessed (Figure 7) ..... N. luykxi

2b. Length with wings $14-16 \mathrm{~mm}$; head width at eyes $>=1.59 \mathrm{~mm}$; eye diameter $0.45-0.54 \mathrm{~mm}$; frons deeply recessed (Figure 8 )..... N. jouteli

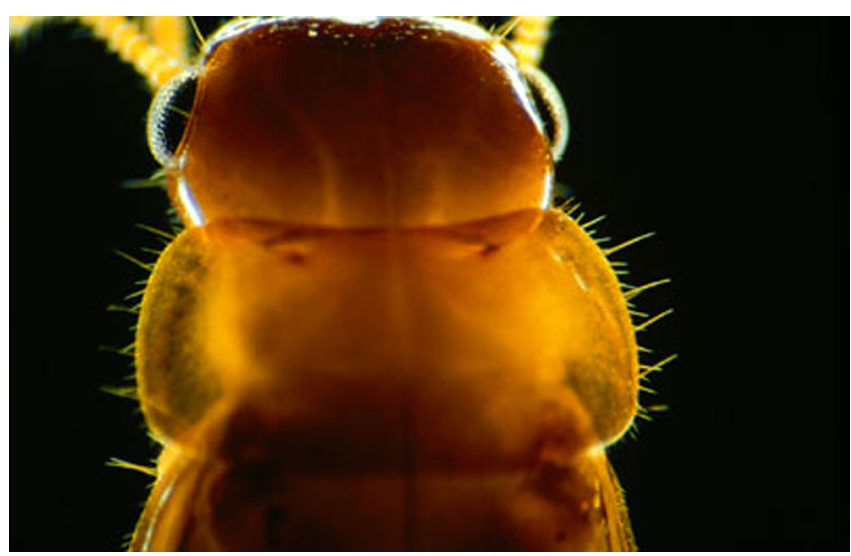

Figure 5. Head and pronotum sparsely covered with long (ca. 0.2-mm-long) hairs; body reddish-brown. ....

Neothermes castaneus (Burmeister). Credits: Rudolf $\mathrm{H}$. Scheffrahn, University of Florida

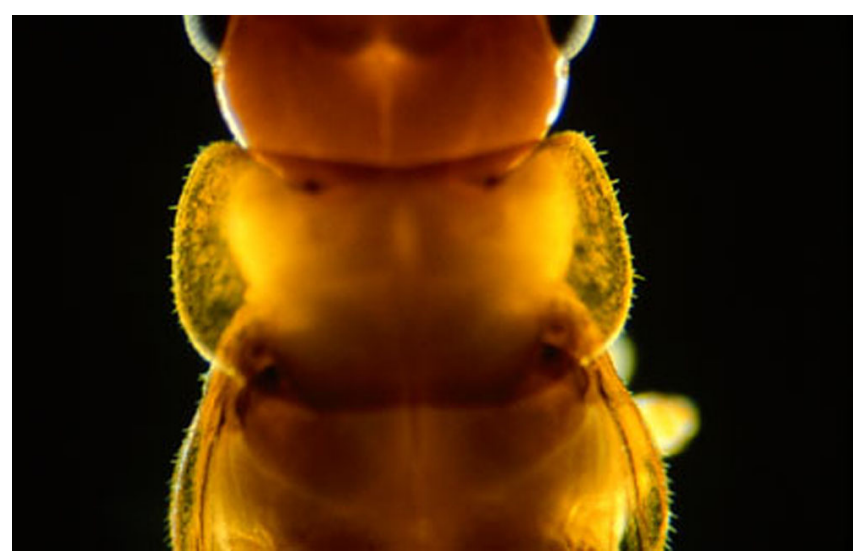

Figure 6. Head and pronotum sparsely covered with short (ca. 0.05-mm-long) hairs; body reddish-orange. Credits: Rudolf $\mathrm{H}$. Scheffrahn, University of Florida

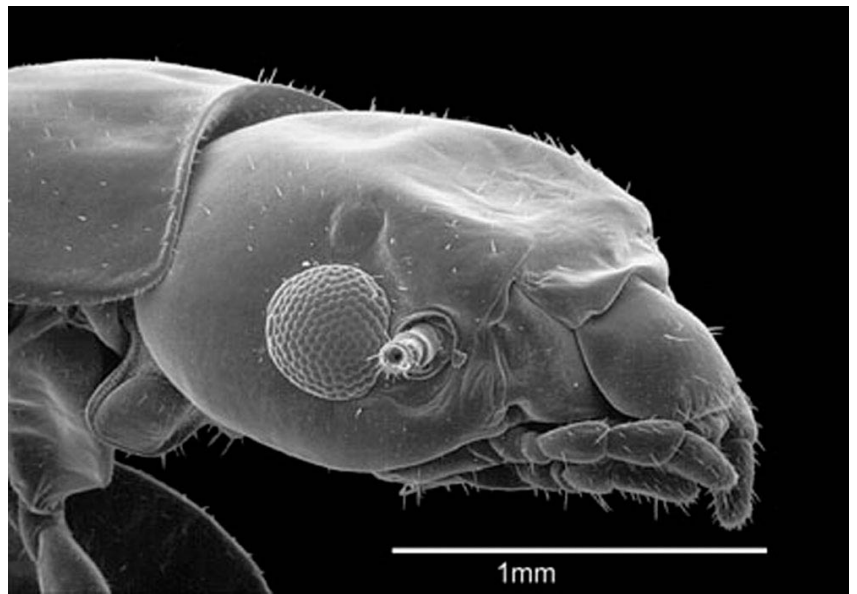

Figure 7. Length with wings $12-14 \mathrm{~mm}$; head width at eyes $<=1.52 \mathrm{~mm}$; eye diameter $0.38-0.42 \mathrm{~mm}$; frons not deeply recessed. .... Neotermes luykxi Nickle and Collins. Credits: Rudolf H. Scheffrahn, University of Florida

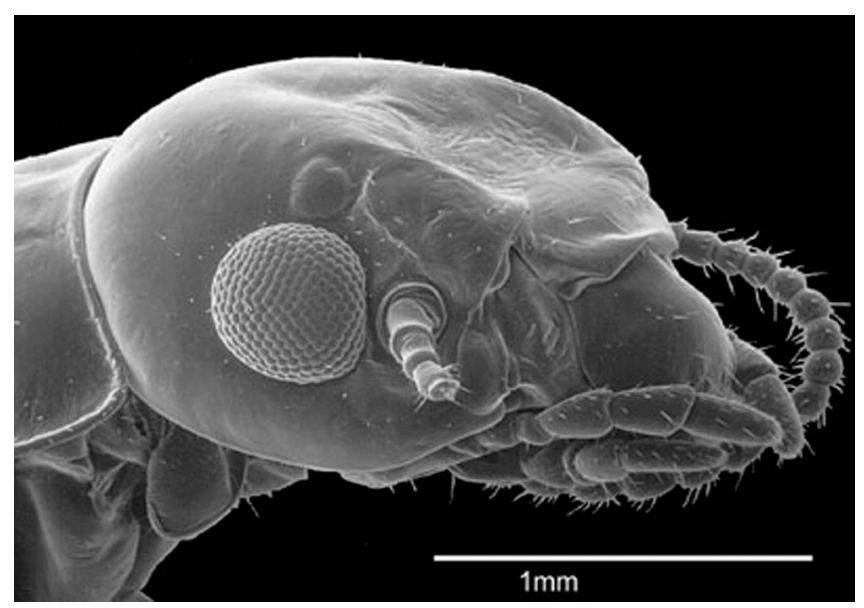

Figure 8. Length with wings $14-16 \mathrm{~mm}$; head width at eyes $>=1.59 \mathrm{~mm}$; eye diameter $0.45-0.54 \mathrm{~mm}$; frons deeply recessed. .... Neotermes jouteli (Banks). Credits: Rudolf H. Scheffrahn, University of Florida

Neotermes soldiers (Figure 9) from the same colony can differ substantially in size, but all are large (8.5-13.5-mm-long) and have at least two marginal teeth visible on their left mandibles. They differ from other termites in Florida in that their pronotum is as wide as the head and, at the same time, the width of the pronotum is much greater than its length. The following key can be used to further distinguish soldiers of the three species of Neotermes found in Florida:

1a. Eye facets unpigmented; third antennal article not clavate, similar to second and fourth (Figure 10). . ... N. castaneus 


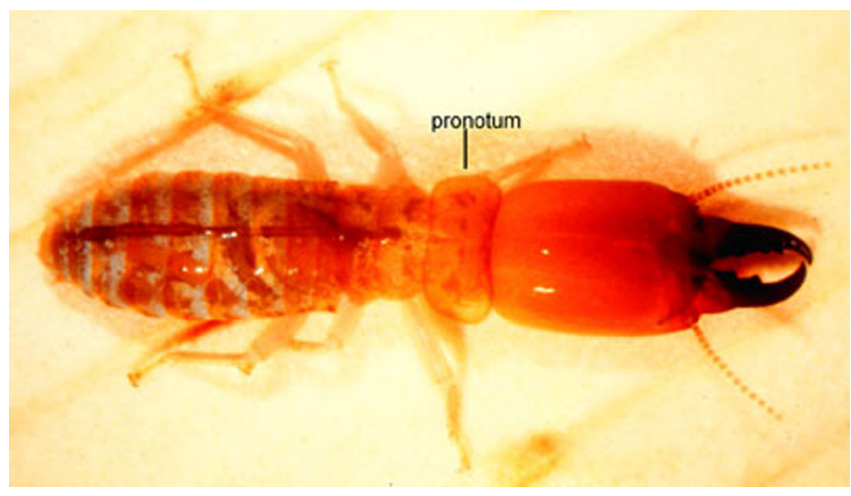

Figure 9. Neotermes castaneus (Burmeister) soldier. Credits: Rudolf H. Scheffrahn, University of Florida

1b. Eye facets darkly pigmented or faintly darkened; third antennal article clavate, longer than second or fourth (Figure 11). . . . 2

2a. Antennal carinae rugose and markedly protruded; eyes elongate, without satellite facets; setae on basal mandibular humps distinct (Figure 12). .....N. jouteli

2b. Antennal carinae smooth and only moderately protruded; eyes subcircular, with satellite facets; setae on basal mandibular humps vestigial or absent (Figure 13)..... N. luykxi

\section{Life History}

As with most other members in the termite family Kalotermitidae, species of Neotermes build networks of galleries that meander through the wood in which they are hidden. Alates leave mature colonies via multiple dispersal flights over "swarming" seasons that can last for several months. Neotermes jouteli and N. luykxi tend to disperse in the late spring or summer, while $N$. castaneus has peak flights in the late fall or early winter. Flights occur at dusk or at night. Dampwood termites are relatively strong fliers and, like most nocturnal flying insects, are attracted to lights. Porch lights, indoor lights, and video monitors often lure the alates inside, especially when doors and unscreened windows are opened. When alates are found indoors, their origin is usually from a yard tree or a woodland colony. Occasionally, alates found indoors originate from an infestation in the structure itself. However, alates flying indoors are unlikely to find the moist wood they need for successful colonization, and are doomed.
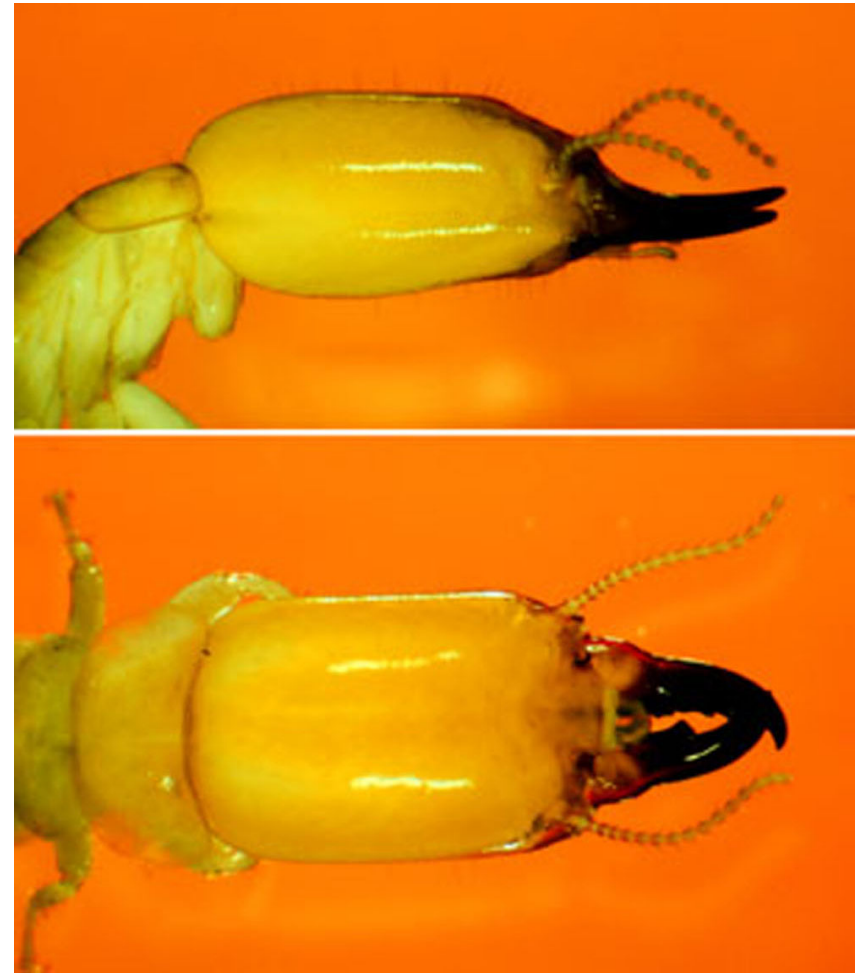

Figure 10. Eye facets unpigmented; third antennal article not clavate, similar to second and fourth. .... Neotermes castaneus (Burmeister) Credits: Rudolf H. Scheffrahn, University of Florida
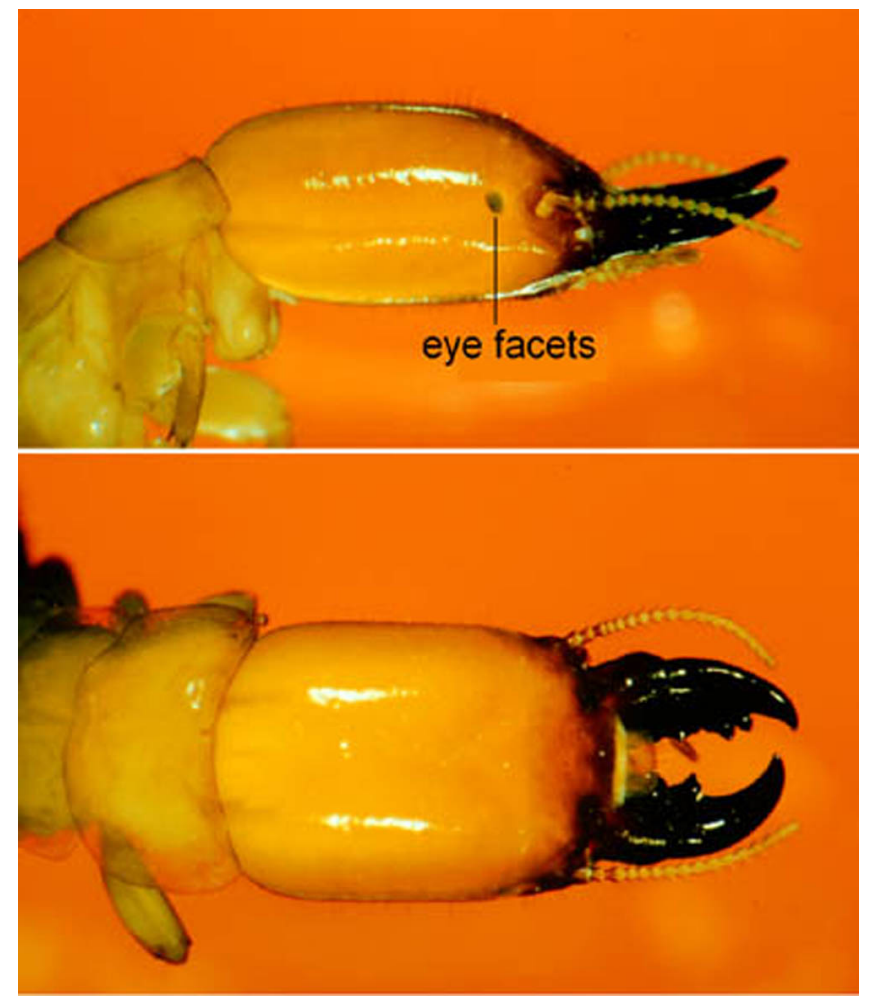

Figure 11. Eye facets darkly pigmented or faintly darkened; third antennal article clavate, longer than second or fourth. Credits: Rudolf H. Scheffrahn, University of Florida 


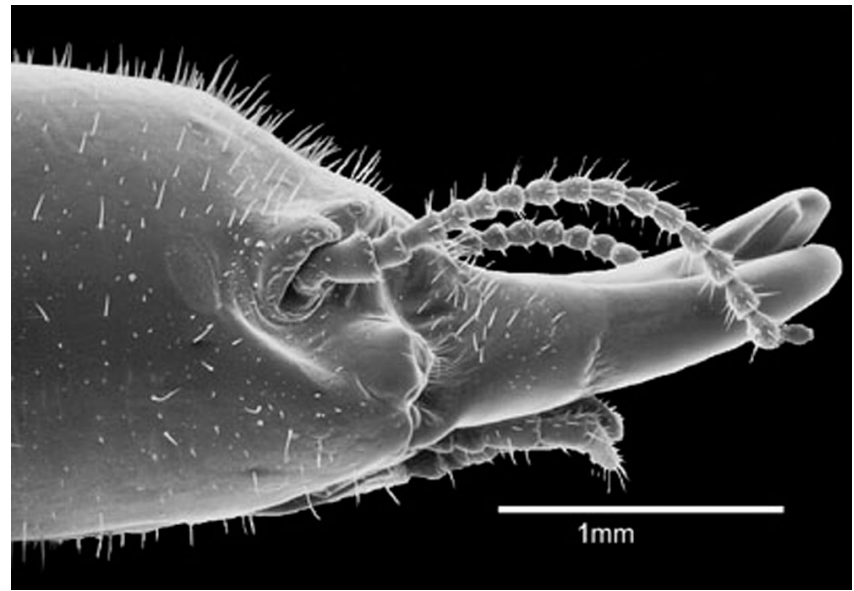

Figure 12. Antennal carinae rugose and markedly protruded; eyes elongate, without satellite facets; setae on basal mandibular humps distinct. .... Neotermes jouteli (Banks). Credits: Rudolf H. Scheffrahn, University of Florida

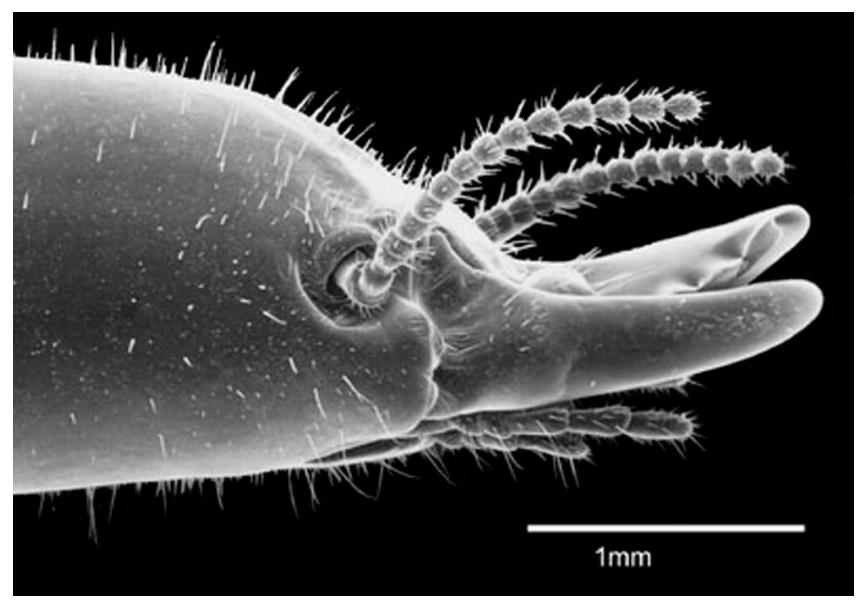

Figure 13. Antennal carinae smooth and only moderately protruded; eyes subcircular, with satellite facets; setae on basal mandibular humps vestigial or absent. ....

Neotermes luykxi Nickle and Collins. Credits: Rudolf $\mathrm{H}$. Scheffrahn, University of Florida

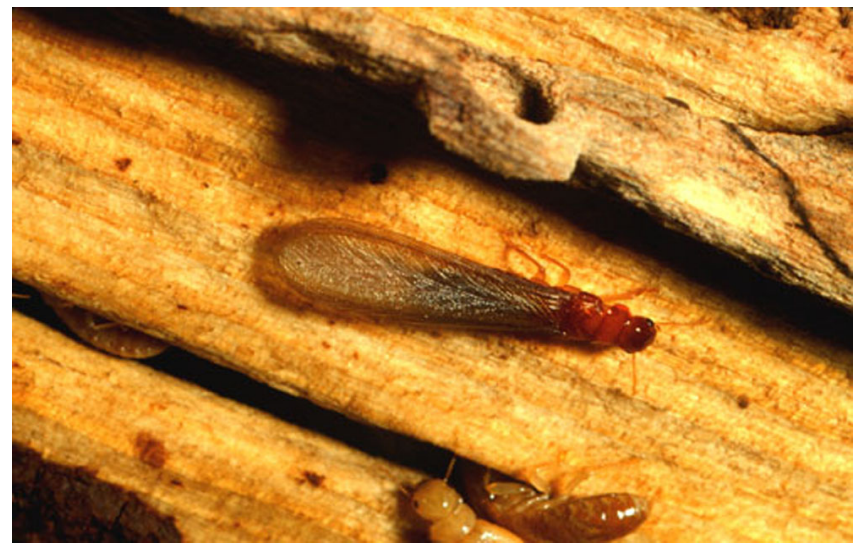

Figure 14. Neotermes castaneus (Burmeister) alate in exposed galleries. Credits: Rudolf H. Scheffrahn, University of Florida
A typical scenario resulting in successful colonization begins with a male and female alate pairing after flight. The pair sheds their wings and selects a nest site such as a crevice in a damp log or untreated fence post, or a pruning scar, tree hole, or other entry into a living tree. The alates then crawl into the existing crack or crevice and seal the entrance with fecal secretion. A few weeks after mating, the queen lays her first batch of eggs. The eggs hatch and the first brood of larvae develop. Over the first few years, additional batches of eggs are laid and the first soldiers appear. After a few more years, when colony population numbers in the hundreds, the first crop of alates molt and the colony begins its own first dispersal cycle. Dampwood termite colony populations can reach several thousand individuals and gallery systems may extend many meters into the wood.

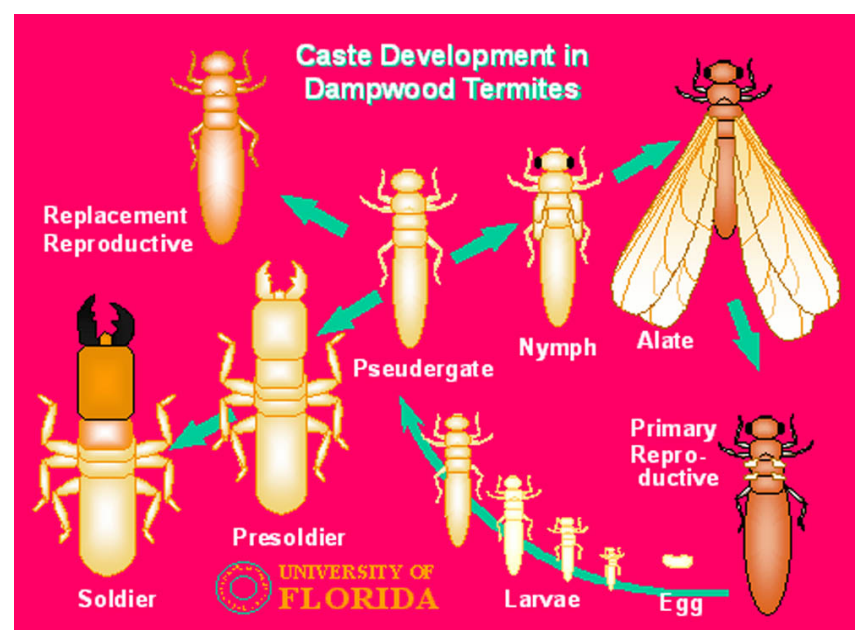

Figure 15. Neotermes life cycle. Credits: Rudolf $\mathrm{H}$. Scheffrahn, University of Florida

\section{Damage}

Because of their moisture requirements, structural infestations of dampwood termites are associated with sources of free water. These include wood-to-soil contact, wood exposed to roof leaks, or wooden siding or ornamentation exposed to rainfall or sprinkler irrigation. Because these same conditions are conducive to fungal decay and subterranean termites, it is in the interest of the property owner to correct these moist conditions. Wood that has been pressure-treated with chromated copper arsenate (CCA) is resistant to infestation. Neotermes infestations can extend into sound dry wood several meters away from the moisture source, but once the 
remote source of moisture is removed, the colony will gradually decline and succumb to desiccation. Like drywood termites, dampwood termites produce fecal pellets, but because of the moist conditions of the gallery system, the pellets loose their distinctive shape and form amorphous clumps or paste. The degree of shape degradation is directly related to moisture content.

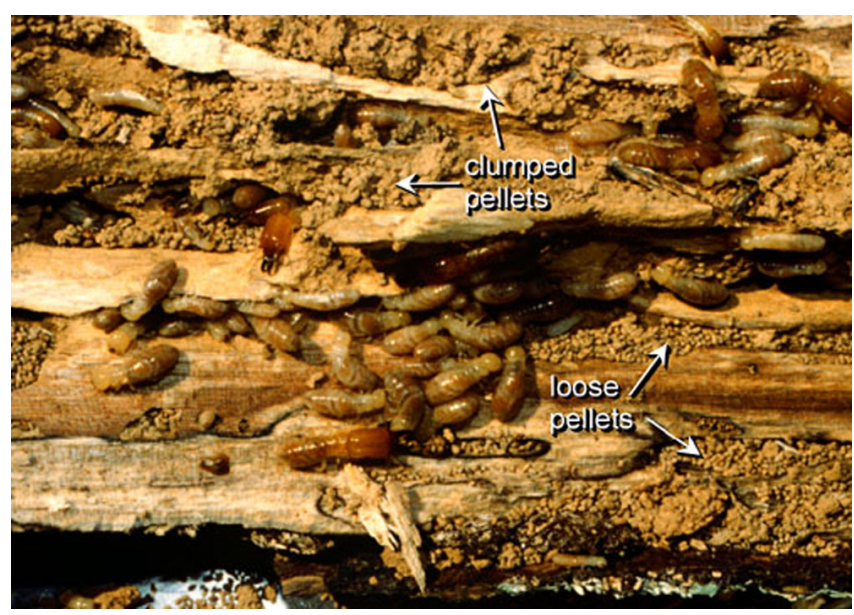

Figure 16. Exposed galleries of Neotermes castaneus (Burmeister) colony in fallen log showing loose and clumped pellets. Credits: Rudolf $\mathrm{H}$. Scheffrahn, University of Florida

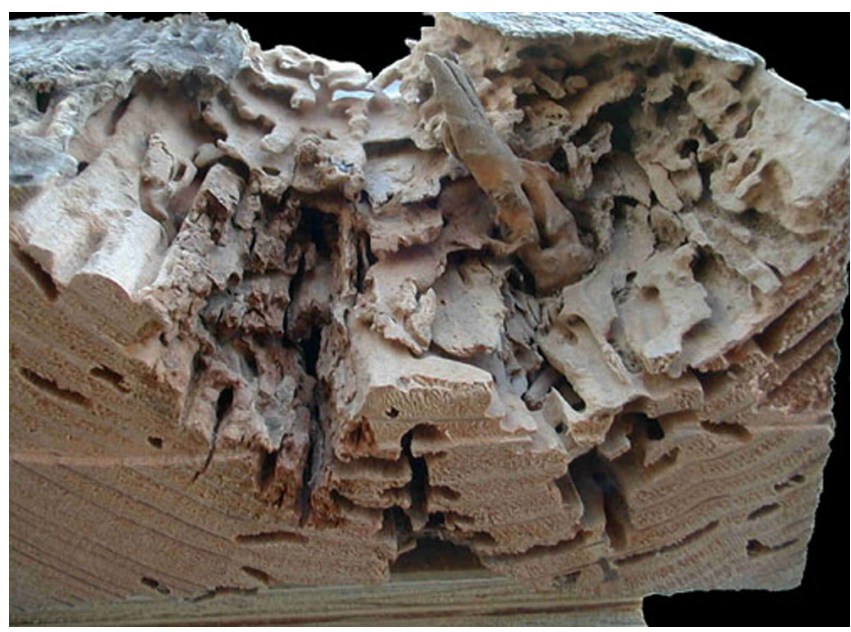

Figure 17. Neotermes jouteli (Banks) damage in 4-inch $\mathrm{x}$ 8-inch beam removed from a house in Ft. Lauderdale. Credits: Rudolf H. Scheffrahn, University of Florida

Neotermes castaneus, in particular, prefers to nest in living trees. Colonies are often discovered in trees when they are pruned or damaged by windstorms. Robust colonies of $N$. castaneus apparently live in trees and palms for years or even decades before they are discovered. In one case, alates of $N$. castaneus were emerging from a Ficus

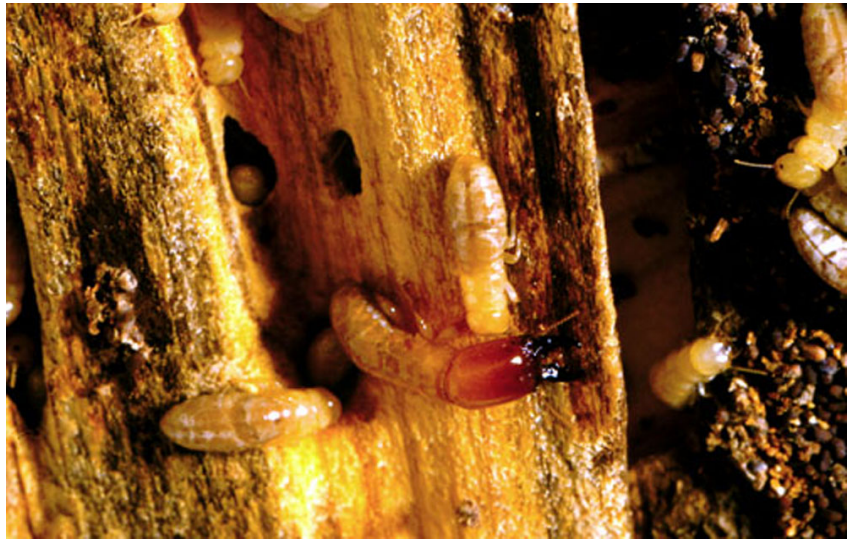

Figure 18. Neotermes jouteli (Banks) soldier and pseudergates in exposed galleries (note fecal pellets). Credits: Rudolf $\mathrm{H}$. Scheffrahn, University of Florida

tree in an indoor shopping mall in New Jersey many years after the tree was delivered from Florida. Although the galleries may weaken trunks and branches, the overall health of the tree is usually not directly affected. The termites appear to limit their feeding to the dead xylem tissues while avoiding the cambium. When galleries filled with live $N$. castaneus are exposed, they exude a characteristic fecal or skatole- like odor.

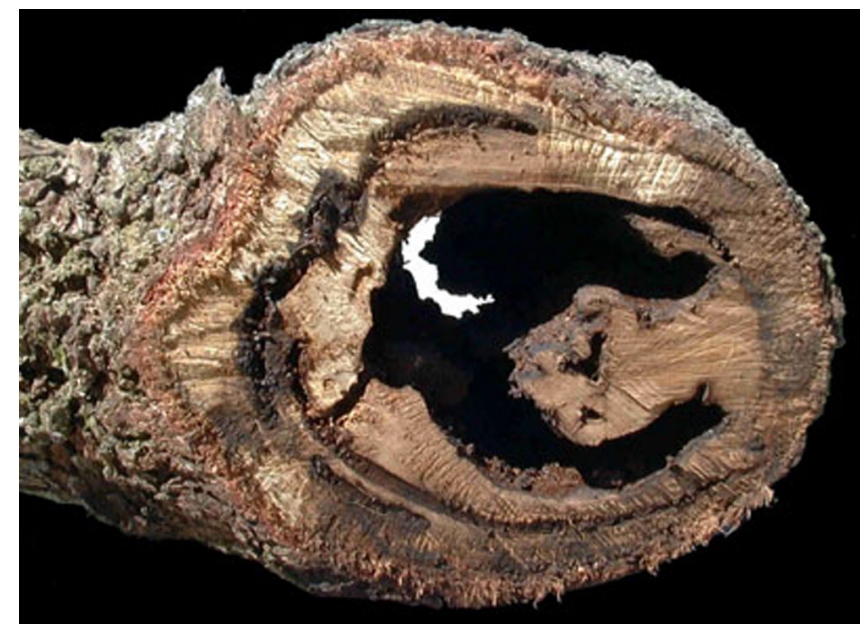

Figure 19. Neotermes castaneus (Burmeister) galleries in oak tree uncovered after pruning (Broward County). Credits: Rudolf H. Scheffrahn, University of Florida

\section{Pest Status}

The limited conditions that support colonization by dampwood termites relegate these termites to minor pest status. Wood damage, however, can be severe after several years if infestations are left alone. Damage to trees and branches may cause weakening but does not appear to harm tree viability although 
hollowing from galleries might promote secondary fungal intrusion.

\section{Management}

For reasons mentioned above, eliminating conditions of moisture can control structural infestations of Neotermes. As with the preventative management of subterranean termites and wood decay, wood-to-ground and wood-to-water contact should be eliminated to prevent colonization by dampwood termites. When untreated wood cannot be removed from a moisture source, chemical treatment may be necessary. Boron-containing salts such as disodium octaborate tetrahydrate (Tim-bor) are water soluble, so they tend to be drawn into dampwood termite-infested wood. Borate treatments can be phytotoxic, however. If desired, galleries in trees or structural members can be injected and drenched with site-specific insecticides. On direct contact, these termites are susceptible to all chemical insecticides.

\section{Selected References}

Nagin, R. 1972. Caste determination in Neotermes jouteli (Banks). Insectes Sociaux 19: 39-61.

Nickle, D.A., and M.S. Collins. 1989. Key to the Kalotermitidae of eastern United States with a new Neotermes from Florida. Proc. Entomol. Soc. Washington 91: 269-285.

Miller, E. M. 1949. A handbook on Florida termites. Univ. of Miami Press, Coral Gables. 30 pp.

Scheffrahn, R. H., J. R. Mangold, and N.-Y. Su. 1988. A survey of structure-infesting termites of peninsular Florida. Florida Entomol. 71: 615- 630.

Scheffrahn, R.H. and N.-Y. Su. 1994. Keys to soldier and winged adult termites (Isoptera) of Florida. Florida Entomol. 77: 460-474.

Scheffrahn, R.H. and N.-Y. Su. Key to termite soldiers of Florida. Ft. Lauderdale Research Report 96-2.

Scheffrahn, R.H. and N.-Y. Su. Key to winged termites of Florida. Ft. Lauderdale Research Report 96-3. 